\title{
Optimasi Fungsi Keanggotaan Fuzzy Mamdani Menggunakan Algoritma Genetika Untuk Penentuan Penerima Beasiswa
}

\author{
Emirza Wira Saputra * \\ Sekolah Tinggi Manajemen Informatika \& Komputer Surya Intan Kotabumi, Jl. Ibrahim Syarif No.107, Kotabumi, Kab. \\ Lampung Utara, Lampung - 34517 \\ erzawira56@gmail.com \\ * Penulis Korespondensi
}

\section{ABSTRAK}

Beasiswa merupakan bantuan pendidikan yang ditujukan untuk meringankan biaya pendidikan sekaligus membantu memperbaiki tingkat pendidikan bangsa. Saat ini banyak beasiswa yang ditawarkan kepada mahasiswa yang kurang mampu dan mahasiswa berprestasi. Untuk mengantisipasi agar beasiswa tersalurkan kepada yang berhak maka diperlukan suatu system mengambil keputusan yang berdasarkan pada enam kriteria utama yaitu Index Prestasis Komulatif (IPK), semester, penghasilan orang Tua, tagihan listrik, pembayaran PBB dan tanggungan orang tua. Pemanfaatan sistem pengambilan keputusan dalam menyelesaikan masalah ketidak tepatan sasaran dalam menentukan penerima beasiswa pada STMIK Surya Intan Kotabumi dengan menggunakan Metode Fuzzy Mamdani dan Metode Algoritma Genetika. Tujuan penelitian ini untuk menerapkan metode Fuzzy Mamdani dan Algoritma Genetika serta mengukur tingkat akurasi metode Fuzzy Mamdani tanpa optimasi dengan metode Fuzzy Mamdani yang teroptimasi menggunakan Algoritma Genetika berdasarkan kriteria-kriteria yang telah ditentukan. Hasil dari penggunaan kedua metode tersebut dengan membandingkan antara metode Fuzzy Mamdani tanpa optimasi sebesar 0,8801 dengan metode Fuzzy Mamdani yang teroptimasi menggunakan Algoritma Genetika sebesar 0,9172 yang diukur menggunakan kolerasi spearman sehingga disimpulkan bahwa penggunaan algoritma genetika dapat mengoptimalkan tingkat kolerasi sebesar 0,0371 .

Kata Kunci : Sistem Penunjang Keputusan, Beasiswa, Fuzzy Mamdani, Algoritma Genetika, Kolerasi Spearman

\section{Pendahuluan}

Saat ini banyak beasiswa yang ditawarkan kepada mahasiswa yang kurang mampu dan mahasiswa berprestasi. Fasilitas beasiswa yang terdapat hampir pada setiap perguruan tinggi dan universitas merupakan bantuan atau reward yang diberikan kepada mahasiswa yang kurang mampu maupun berprestasi. Namun proses penyeleksian Beasiswa yang sedang berjalan pada STMIK Surya Intan Kotabumi, masih dilakukan secara manual dan terkadang terdapat masalah salah satunya yaitu ketidaktepatan sasaran beasiswa yang diberikan kepada mahasiswa karena adanya unsur subyektifitas dan ketidakkonsistenan dari tim penilai.

Untuk mengantisipasi agar beasiswa tersalurkan kepada yang berhak maka diperlukan suatu system mengambil keputusan yang berdasarkan pada enam kriteria utama yaitu Index Prestasis Komulatif (IPK), semester, penghasilan orang Tua, tagihan listrik, pembayaran PBB dan tanggungan orang tua. Proses seleksi penerimaan beasiswa ini merupakan salah satu permasalahan yang sering diangkat sebab di khawatirkan penyaluran tidak tepat sasaran.

Kedua metode berikut dipilih karena metode Fuzzy Mamdani merupakan suatu bentuk model pendukung keputusan dimana dalam menentukan fungsi keanggotaan masih berdasarkan persepsi manusia, yakni dalam hal ini adalah orang yang ahli dalam masalah pemilihan beasiswa. 
Sedangkan metode Algoritma Genetika merupakan suatu bentuk tipe Evolution Algorithm (EA) yang paling populer karena kemampuannya untuk menyelesaikan berbagai masalah kompleks sehingga diharapkan dengan menggunakan metode Algoritma Genetika dalam mengoptimasi fungsi keanggotaan Fuzzy Mamdani.

\section{Landasan Teori}

\subsection{Sistem Pendukung Keputusan}

"Sistem pendukung keputusan adalah suatu sistem informasi spesifik yang ditujukan untuk membantu manajemen dalam mengambil keputusan yang berkaitan dengan persoalan yang bersifat semi terstruktur. Sistem ini memiliki fasilitas untuk menghasilkan berbagai alternatif yang secara interaktif digunakan oleh pemakai" [1].

\subsection{Pengertian Beasiswa}

"Beasiswa adalah pemberian berupa bantuan keuangan yang diberikan kepada perorangan yang bertujuan untuk digunakan demi keberlangsungan pendidikan yang ditempuh. Beasiswa dapat diberikan oleh lembaga pemerintah, perusahaan ataupun yayasan" [2].

\subsection{Pengertian Logika Fuzzy}

"Logika Fuzzy adalah konsep yang tepat untuk menangani masalah nonlinear, waktu yang beravariasi dan sistem adaptif. Logika Fuzzy ini memungkinkan penggunaan nilai-nilai linguistik dari variabel dan hubungan tidak tepat untuk perilaku sistem modeling. Logika Fuzzy sering digunakan pada sistem cerdas dalam memilah proses untuk mendeteksi cacat dalam penerapannya" [3].

"Salah satu aplikasi yang paling terkenal dari logika Fuzzy adalah Fuzzy inference system (FIS). Ada tiga jenis dasar FIS yang telah banyak digunakan dalam berbagai aplikasi kontrol, yaitu FIS Mamdani, Sugeno, dan Tsukamoto. Perbedaan antara tiga FIS ini terletak pada konsekuen dari aturan Fuzzy mereka, agregasi dan prosedur defuzzifikasi" [4]. Ada beberapa alasan mengapa orang menggunakan logika Fuzzy, antar lain [5]:

a) Konsep logika Fuzzy mudah dimengerti. Konsep matematis yang mendasari penalaran

Fuzzy sangat sederhana dan mudah dimengerti.

b) Logika Fuzzy sangat fleksibel.

c) Logika Fuzzy memiliki toleransi terhadap data yang tidak tepat.

d) Logika Fuzzy mampu memodelkan fungsi nonlinier yang sangat kompleks.

e) Logika Fuzzy dapat membangun dan mengaplikasikan pengalaman para pakar secara langsung tanpa harus melalui proses pelatihan.

f) Logika Fuzzy dapat bekerjasama dengan teknik kendali secara konvensional.

g) Logika Fuzzy didasarkan pda bahasa alami.

Ada beberapa tahap yang harus diketahui untuk menghitung nilai di dalam logika Fuzzy, yaitu :
a) Fungsi keanggotaan
b) Fuzzifikasi
c) Operasi himpunan Fuzzy
d) Defuzzifikasi

\subsection{Fungsi Keanggotaan}


"Fungsi keanggotaan didefinisikan sebagai representasi grafis dari besarnya keikutsertaan setiap input (masukan). Fungsi keanggotaan ini menghubungkan bobot dengan masingmasing input yang diproses,mendefinisikan tumpang tindih di antarainput, dan akhirnya menentukan respon output (keluaran). Aturan menggunakan nilai keanggotaan input sebagai faktor pembobotan untuk menentukanpengaruhnya terhadap set output Fuzzy kesimpulan hasil akhir" [3].

Jika fungsi keanggotaan tidak sesuai, maka hasil yang didapat akan jauh berbeda dari diharapkan. Fungsi keanggotaan ini merupakan tahap awal dan paling penting untuk menuju tahap fuzzifikasi. Fuzzifikasi merupakan tahap dimana nilai inputan yang berupa nilai crisp (tegas) diubah menjadi nilai Fuzzy [6].

\section{Representasi Linear Naik}

Pada representasi linear, pemetaan input ke derajat keanggotaannya digambarkan sebagai sebuah garis lurus sebagai berikut :

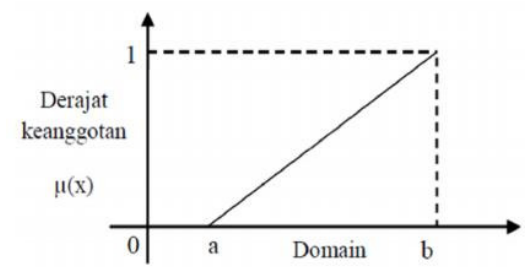

Gambar 1 Representasi linear naik

Fungsi keanggotaan representasi linear naik

$$
\boldsymbol{\mu}[\boldsymbol{x}]=\left\{\begin{array}{lr}
\mathbf{0} ; & \boldsymbol{x} \leq \boldsymbol{a} \\
\frac{\boldsymbol{x}-\boldsymbol{a}}{\boldsymbol{b}-\boldsymbol{a}} ; & \boldsymbol{a} \leq x \leq \boldsymbol{b} \\
\mathbf{1} ; & \boldsymbol{x} \geq \boldsymbol{b}
\end{array}\right.
$$

\section{Representasi Linear Turun}

Reprensentasi ini merupakan kebalikan dari representasi linear naik. sebagai berikut:

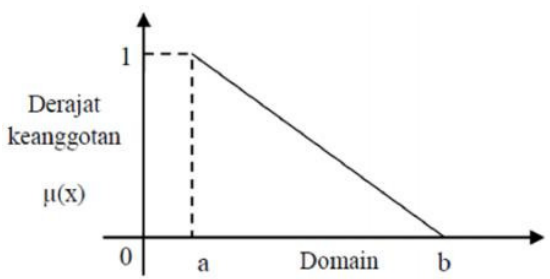

Gambar 2 Representasi linear turun

Fungsi keanggotaan representasi linear turun

$\boldsymbol{\mu}[\boldsymbol{x}]=\left\{\begin{array}{cc}\frac{b-\boldsymbol{x}}{\boldsymbol{b}-\boldsymbol{a}} ; & \boldsymbol{a} \leq x \leq \boldsymbol{b} \\ 0 ; & \boldsymbol{x} \geq \boldsymbol{b}\end{array}\right.$ 


\section{Representasi Kurva Segitiga}

Reprensitasi kurva segitiga pada dasarnya merupakan gabungan antara linear naik dan linear turun sebagai berikut:

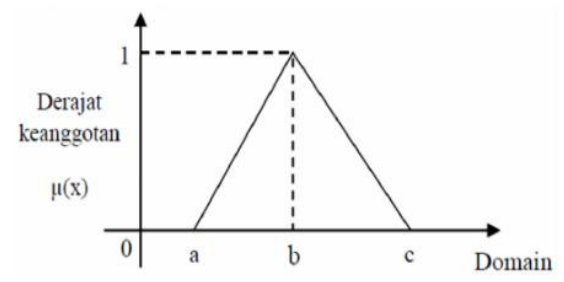

Gambar 3 Representasi kurva segitiga

Fungsi keanggotaan representasi kurva segitiga

$$
\mu[x]=\left\{\begin{array}{lr}
0: & x \leq a \text { atau } x \geq c \\
\frac{x-a}{b-a} ; & a \leq x \leq b \\
\frac{c-x}{c-b} ; & b \leq x \leq c
\end{array}\right.
$$

\section{Representasi Kurva Trapesium}

Reprensitasi kurva trapesium memiliki domain lebih luas dari representasi kurva segitiga sebagai berikut:

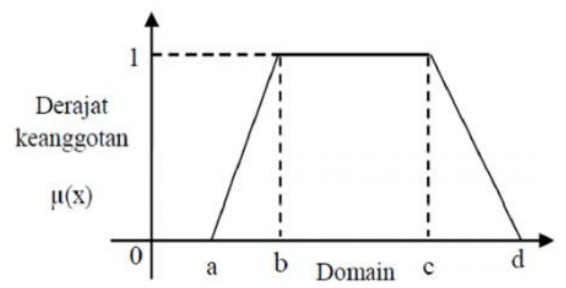

Gambar 4 Representasi kurva trapesium

Fungsi keanggotaan representasi kurva trapesium

$$
\mu[x]=\left\{\begin{array}{lr}
0: & x \leq \text { a atau } x \geq d \\
\frac{x-a}{b-a} ; & a \leq x \leq b \\
\mathbf{1} ; & b \leq x \leq c \\
\frac{d-x}{d-c} ; & c \leq x \leq d
\end{array}\right.
$$

\subsection{Komponen-Komponen Utama Algoritma Genetika}

Beberapa komponen utama yang harus dilakukan untuk mengimplementasikan Algoritma Genetika adalah sebagai berikut [9].

1) Teknik Encoding/Decoding Gen dan Individu/Decoding merupakan suatu cara pengkodean isi kromosom menjadi suatu nilai tertentu yang mana hasil dekodenya mewakili tiap variabel dan terdiri dari beberapa jumlah bit yang ada. 
2) Membangkitkan Populasi Awal Sebelum membangkitkan populasi awal, terlebih dahulu harus menentukan ukuran individu dalam populasi tesebut. Dalam tahap ini akan ditentukan ukuran populasi (popSize), nilai ini digunakan untuk menyatakan banyaknya individu yang akan ditampung dalam individu

3) Nilai fitness menyatakan nilai dari fungsi tujuan. Tujuan dari algoritma genetika adalah memaksimalkan nilai fitness.

Proses fitness dapat dilakukan dengan persamaan berikut ini : Fitness $=\mathrm{c}-\mathrm{f}(\mathrm{x})$

Fitness $=\mathrm{C} /(\mathrm{f}(\mathrm{x})+\varepsilon)$

Keterangan :

$\mathrm{C}=$ Konstanta

$\varepsilon=$ Bilangan kecil yang ditentukan untuk menghindari agar tidak terjadi pembagian oleh nol

$\mathrm{X}=$ individu

Analisis korelasi digunakan untuk mengetahui tingkat hubungan antara dua variabel atau lebih variabel bebas $(\mathrm{Xi})$ dengan variabel terikatnya (Yi) yang berskala ordinal menggunakan metode korelasi Rank Spearman untuk menguji hipotesis 1 dan hipotesis 2.

\section{4) Seleksi}

Seleksi dilakukan untuk memilih individu dari himpunan individu dan offspring yang dipertahankan untuk generasi berikutnya. Terdapat beberapa metode seleksi yang dapat digunakan yaitu Variabel $\mathrm{X}$ dan $\mathrm{Y}$ diukur dengan skala ordinal sehingga objek yang diteliti dapat dirangking dalam rangkaian yang berurutan. Menghitung Roulette Wheel selection, Rank Selection, Elitism dan sebagainya.

\section{5) Crossover (Pidah Silang)}

Sebuah individu yang mengarah pada solusi optimal bisa diperoleh melalui proses pindah silang. Di dalam proses crossover ditentukan tingkat crossover (crossover rate). Nilai ini digunakkan untuk menyatakan rasio offspring (keturunan) sehingga dihasilkan offspring sebnayak crossrate x popSize.

\section{6) Penggantian Populasi}

Penggantian populasi dimaksudkan bahwa semua individu mendapatkan individu baru yang terbaik.

\section{Metode}

Pendekatan yang digunakan dalam penelitian ini adalah penelitian kuantitatif. Penulis melakukan penelitian guna memperoleh data dan informasi yang akurat pada STMIK Surya Intan Kotabumi yang berlokasi di Kotabumi, Lampung Utara. Populasi dalam penelitian ini adalah seluruh mahasiswa yang terdaftar sebagai calon penerima beasiswa di STMIK Surya Intan Kotabumi. Subjek penelitian yang akan menjadi sampel dalam penelitian ini sejumlah 30 (tiga puluh) mahasiswa.

\subsection{Langkah-Langkah MetodenFuzzy Mamdani}

Adapun langkah-langkah dalam perancangan sistem pada metode Fuzzy Mamdani sebagai berikut : 


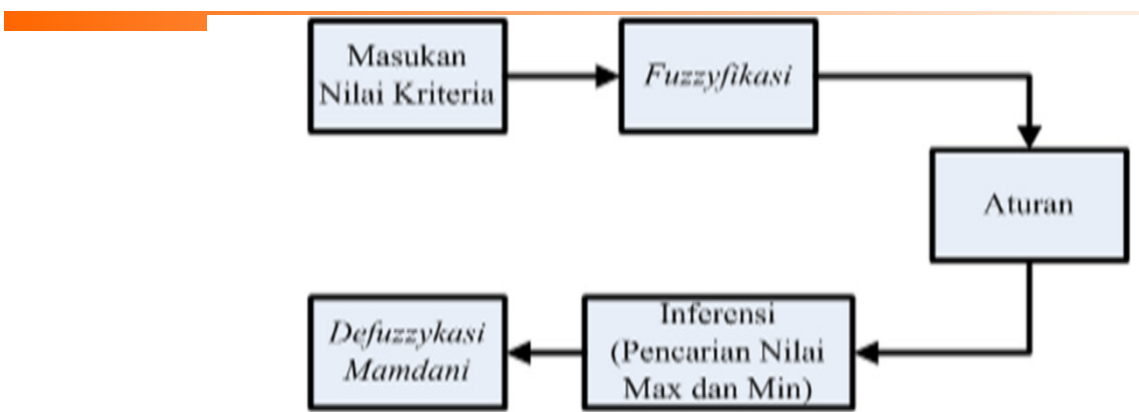

Gambar 6 Langkah-langkah Fuzzy Mamdanai

3.2.

\section{Langkah-Langkah Optimasi Fugsi Keanggotaan Fuzzy Mamdani Menggunakan Algoritma Genetika}

Adapun langkah-langkah dalam perancangan sistem sebagai berikut :

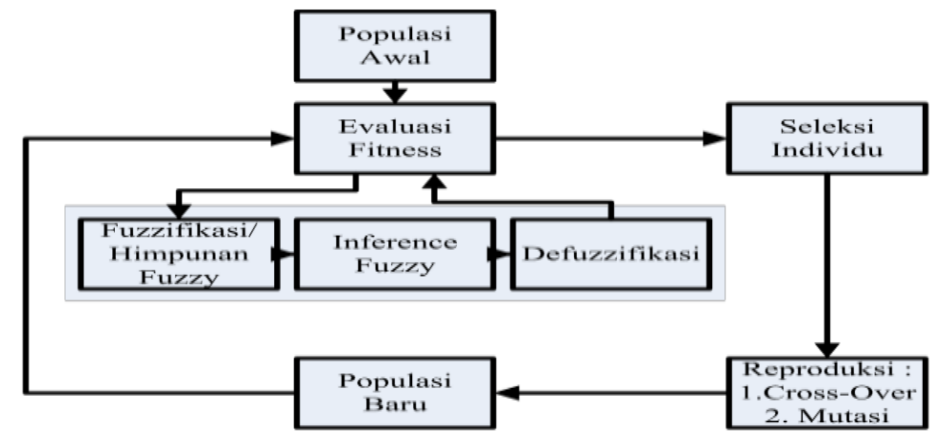

Gambar 7 Diagram optimasi Fuzzy Mamdanai dan Algoritma

\subsection{Metode Evaluasi}

Model yang dihasilkan dari Metode Fuzzy Mamdani dan metode Fuzzy Mamdani yang dioptimalkan menggunakan Algoritma Genetika diuji menggunakankan pengujian korelasi Rank Spearman.

\section{Hasil dan Pembahasan}

\subsection{Metode Fuzzy Mamdani}

langkah-langkah perhitungan metode Fuzzy Mamdani sebagai berikut :

\section{Variabel Penelitian}

Kriteria yang digunakan sebagai berikut: 
Tabel 1 Variabel Input Himpunan Fuzzy

\begin{tabular}{|c|c|c|c|}
\hline No & Variabel & Himpunan Fuzzy & Domain \\
\hline & Input & & \\
\hline \multirow{3}{*}{1} & \multirow{3}{*}{ IPK } & Rendah & $2,00-3,00$ \\
\hline & & Sedang & $2,50-3,50$ \\
\hline & & Tinggi & $3,00-4.00$ \\
\hline \multirow{3}{*}{2} & \multirow{3}{*}{ Semester } & Rendah & $2-4$ \\
\hline & & Sedang & $3-5$ \\
\hline & & Tinggi & $4-6$ \\
\hline \multirow{3}{*}{3} & \multirow{3}{*}{ Penghasilan Orang Tua } & Rendah & Rp. $50.000-$ Rp. 2.050 .000 \\
\hline & & Sedang & Rp. $1.050 .000-$ Rp. 3.050 .000 \\
\hline & & Tinggi & Rp. 2.050 .000 - Rp. 4.050 .000 \\
\hline \multirow{3}{*}{4} & \multirow{3}{*}{ Tagihan Listrik } & Rendah & Rp. $20.000-$ Rp. 220.000 \\
\hline & & Sedang & Rp. 120.000 - Rp. 320.000 \\
\hline & & Tinggi & Rp. 220.000 - Rp. 420.000 \\
\hline \multirow{3}{*}{5} & \multirow{3}{*}{ Pembayaran PBB } & Rendah & Rp. $20.000-$ Rp. 220.000 \\
\hline & & Sedang & Rp. 120.000 - Rp. 320.000 \\
\hline & & Tinggi & Rp. 220.000 - Rp. 420.000 \\
\hline \multirow{3}{*}{6} & \multirow{3}{*}{ Tanggungan Orang Tua } & Rendah & 1-3 anak \\
\hline & & Sedang & $2-4$ anak \\
\hline & & Tinggi & 3-5 anak \\
\hline \multirow{3}{*}{1} & Output & & \\
\hline & Keputusan Beasiswa & Diterima & 70 \\
\hline & & Ditolak & 20 \\
\hline
\end{tabular}

\section{Fungsi Keanggotaan}

1) IPK (Indeks Prestasi Komulatif)

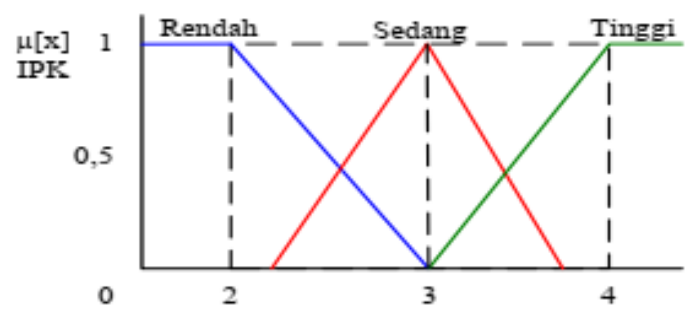

Gambar 8 Fungsi Keanggotaan IPK (Indeks Prestasi Komulatif)

Fungsi keanggotaan:

$$
\begin{aligned}
& \mu_{I P K \text { Rendah }}[x] \\
& =\left\{\begin{array}{cc}
1 ; & x \leq 2,00 \\
\frac{(3,00-x)}{(3,00-2,00)} & 2,00 \leq x \leq 3,00 \\
0 ; & x \geq 3,00
\end{array}\right.
\end{aligned}
$$




$$
\begin{aligned}
& \mu_{I P K \text { Sedang }}[x] \\
& =\left\{\begin{array}{cc}
0 ; & x \leq 2,50 \text { or } x \geq 3,50 \\
\frac{(x-2,50)}{(3,00-2,50)} & 2,50 \leq x \leq 3,00 \\
\frac{(3,50-x)}{(3,50-3,00)} & 3,00 \leq x \leq 3,50
\end{array}\right. \\
& \mu_{I P K \text { Tinggi }[x]}\left[\begin{array}{cc}
0 ; & x \leq 3,00 \\
\frac{(x-3,00)}{(4,00-3,00)} & 3,00 \leq x \leq 4,00 \\
1 ; & x \geq 4,00
\end{array}\right.
\end{aligned}
$$

2) Semester

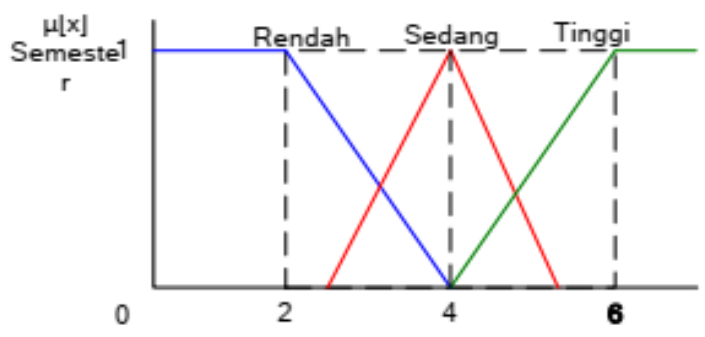

Gambar 9 Fungsi Keanggotaan Semester

$$
\begin{aligned}
& \text { Fungsi Keanggotaan } \\
& \mu_{\text {Semester Rendah }}[x] \\
& =\left\{\begin{array}{cc}
1 ; & (4-x) \\
(4-2) & 2 \leq x \leq 4 \\
0 ; & x \geq 4
\end{array}\right. \\
& \mu_{\text {Semester Sedang }}[x] \\
& =\left\{\begin{array}{cc}
0 ; & x \leq 3 \text { or } x \geq 5 \\
\frac{(x-3)}{(4-3)} & 3 \leq x \leq 4 \\
\frac{(5-x)}{(5-4)} & 4 \leq x \leq 5
\end{array}\right. \\
& \mu_{\text {Semester Tinggi }}[x] \\
& =\left\{\begin{array}{cc}
0 ; & x \leq 4 \\
\frac{(x-4)}{(6-4)} & 4 \leq x \leq 6 \\
1 ; & x \geq 6
\end{array}\right.
\end{aligned}
$$

3) Penghasilan Orang Tua 


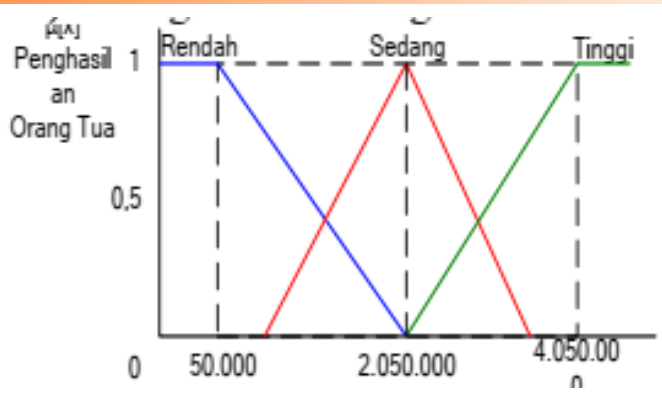

Gambar 10 Fungsi Keanggotaan Penghasilan Orang Tua

\section{Fungsi Keanggotaan}

$$
\begin{aligned}
& \mu_{\text {Penghasilan Rendah }}[x] \\
& =\left\{\begin{array}{cc}
1 ; & x \leq 50 \\
\frac{(2.050-x)}{(2.050-50)} & 50.000 \leq x \leq 2.050 \\
0 ; & x \geq 2.050
\end{array}\right.
\end{aligned}
$$

$\mu_{\text {Penghasilan Sedang }}[x]$

$$
=\left\{\begin{array}{cc}
0 ; & x \leq 1.050 \text { or } x \geq 3.050 \\
\frac{(x-1.050 .)}{(2.050-1.050)} & 1.050 \leq x \leq 2.050 \\
\frac{(3.000-x)}{(3.000-2.000)} & 2.050 \leq x \leq 3.050
\end{array}\right.
$$

$\mu_{\text {Penghasilan Tinggi }}[x]$

$$
=\left\{\begin{array}{ccrl}
0 ; & x & \leq 2.050 \\
\frac{(x-2.050)}{(4.050-2.050)} & 2.050 & \leq x \leq 4.050 \\
1 ; & x & \geq 4.050
\end{array}\right.
$$

4) Tagihan Listrik

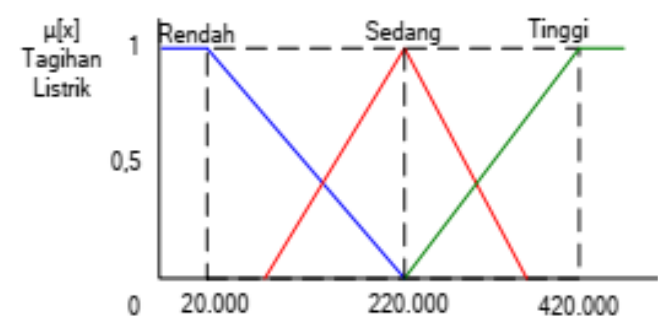

Gambar 11 Fungsi Keanggotaan Tagihan Listrik 


$$
\begin{aligned}
& \text { Fungsi Keanggotaan } \\
& \mu_{\text {Tagihan Listrik Rendah }}[x] \\
& =\left\{\begin{array}{cc}
1 ; & x \leq 20.000 \\
\frac{(220.000-x)}{(220.000-20.000)} & 20.000 \leq x \leq 220.000 \\
0 ; & x \geq 220.000
\end{array}\right.
\end{aligned}
$$

$\mu_{\text {Tagihan Listrik Sedang }}[x]$

$$
=\left\{\begin{array}{cc}
0 ; & x \leq 120.000 \text { or } x \geq 320.000 \\
\frac{(x-120.000)}{(220.000-120.000)} & 120.000 \leq x \leq 220.000 \\
\frac{(320.000-x)}{(320.000-220.000)} & 220.000 \leq x \leq 320.000
\end{array}\right.
$$

$\mu_{\text {Tagihan Listrik Tinggi }}[x]$

$$
=\left\{\begin{array}{cc}
0 ; & x \leq 220.000 \\
\frac{(x-220.000)}{(420.000-220.000)} & 220.000 \leq x \leq 420.000 \\
1 ; & x \geq 420.000
\end{array}\right.
$$

5) Pembayaran PBB

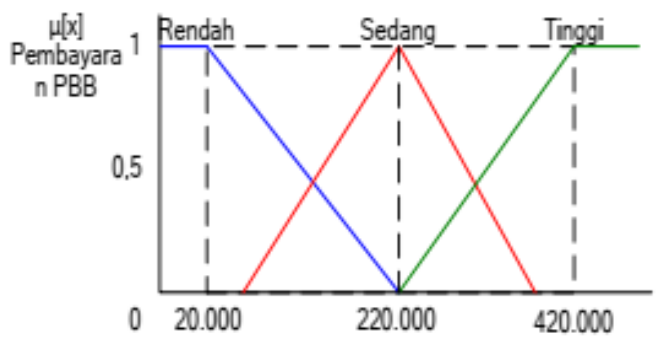

Gambar 12 Fungsi Keanggotaan Pembayaran PBB

\section{Fungsi Keanggotaan}

$=$

$\mu_{\text {Pembayaran PBB Rendah }}[x]$

$$
=\left\{\begin{array}{cc}
1 ; & x \leq 20.000 \\
\frac{(220.000-x)}{(220.000-20.000)} & 20.000 \leq x \leq 220.000 \\
0 ; & x \geq 220.000
\end{array}\right.
$$

$\mu_{\text {Pembayaran PBB Sedang }}[x]$

$=\left\{\begin{array}{cc}(x-120.000) & x \leq 120.000 \text { or } x \geq 320.000 \\ \frac{(220.000-120.000)}{(320.000-x)} & 120.000 \leq x \leq 220.000 \\ \frac{(320.000-220.000)}{(320.000 \leq x \leq 320.000} & \end{array}\right.$

$\mu_{\text {Pembayaran PBB Tinggi }}[x]$

$$
=\left\{\begin{array}{cc}
(x-220.000) & x \leq 220.000 \\
\hline(420.000-220.000) & 220.000 \leq x \leq 420.000 \\
1 ; & x \geq 420.000
\end{array}\right.
$$


6) Tanggungan Orang Tua

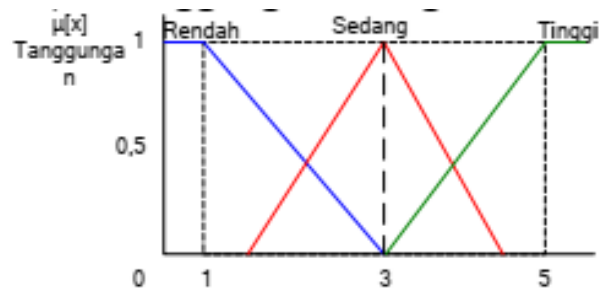

Gambar 13 Fungsi Keanggotaan Tanggungan Orang Tua

Fungsi Keanggotaan

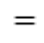

$\mu_{\text {Tanggungan Rendah }}[x]=$

$\left\{\begin{array}{cc}1 ; & x \leq 1 \\ \frac{(3-x)}{(3-1)} & 1 \leq x \leq 3 \\ 0 ; & x \geq 3\end{array}\right.$

$\mu_{\text {Tanggungan Sedang }}[x]$

$=\left\{\begin{array}{cc}0 ; & x \leq 2 \text { or } x \geq 4 \\ \frac{(x-2)}{(3-2)} & 2 \leq x \leq 3 \\ \frac{(4-x)}{(4-3)} & 3 \leq x \leq 4\end{array}\right.$

$\mu_{\text {Tanggungan Tinggi }}[x]$

$=\left\{\begin{array}{cc}0 ; & x \leq 3 \\ \frac{(x-3)}{(5-3)} & 3 \leq x \leq 5 \\ 1 ; & x \geq 5\end{array}\right.$

\section{Rule IF-THEN}

Dalam penelitian ini terdapat 6 kriteria input, berdasarkan unit penalaran yang terdapat 324 Rule himpunan Fuzzy, maka akan terbentuk aturan-aturan yang terdapat pada tabel 2 berikut:

Tabel 2 Rule IF-THEN

\begin{tabular}{|c|c|c|c|c|c|c|c|}
\hline No & IPK & Semester & $\begin{array}{c}\text { Penghasilan } \\
\text { Orang Tua }\end{array}$ & $\begin{array}{c}\text { Tagihan } \\
\text { Listrik }\end{array}$ & $\begin{array}{c}\text { Pembayaran } \\
\text { PBB }\end{array}$ & $\begin{array}{c}\text { Tanggungan } \\
\text { orang tua }\end{array}$ & $\begin{array}{c}\text { Keputusan } \\
\text { Beasiswa }\end{array}$ \\
\hline 1 & Sedang & Rendah & Rendah & Rendah & Rendah & Rendah & Diterima \\
\hline 2 & Sedang & Rendah & Rendah & Rendah & Rendah & Sedang & Diterima \\
\hline 3 & Sedang & Rendah & Rendah & Rendah & Rendah & Tinggi & Diterima \\
\hline 4 & Sedang & Rendah & Rendah & Rendah & Sedang & Sedang & Diterima \\
\hline 5 & Sedang & Rendah & Rendah & Rendah & Sedang & Tinggi & Diterima \\
\hline 6 & Sedang & Rendah & Rendah & Rendah & Tinggi & Tinggi & Diterima \\
\hline 7 & Sedang & Rendah & Rendah & Sedang & Rendah & Sedang & Diterima \\
\hline 8 & Sedang & Rendah & Rendah & Sedang & Rendah & Tinggi & Diterima \\
\hline 9 & Sedang & Rendah & Rendah & Sedang & Sedang & Tinggi & Diterima \\
\hline 10 & Sedang & Rendah & Rendah & Tinggi & Rendah & Tinggi & Diterima \\
\hline 11 & Sedang & Rendah & Sedang & Rendah & Rendah & Sedang & Diterima \\
\hline 12 & Sedang & Rendah & Sedang & Rendah & Rendah & Tinggi & Diterima \\
\hline 13 & Sedang & Rendah & Sedang & Rendah & Sedang & Tinggi & Diterima \\
\hline 14 & Sedang & Rendah & Sedang & Sedang & Rendah & Tinggi & Diterima \\
\hline 15 & Sedang & Sedang & Rendah & Rendah & Rendah & Rendah & Diterima \\
\hline 16 & Sedang & Sedang & Rendah & Rendah & Rendah & Sedang & Diterima \\
\hline 17 & Sedang & Sedang & Rendah & Rendah & Rendah & Tinggi & Diterima \\
\hline$\vdots$ & $\vdots$ & $\vdots$ & $\vdots$ & $\vdots$ & $\vdots$ & $\vdots$ & $\vdots$ \\
\hline & $\vdots$ & $\vdots$ & $\vdots$ & $\vdots$ & $\vdots$ & $\vdots$ \\
\hline 324 & Tinggi & Tinggi & Sedang & Tinggi & Tinggi & Sedang & Ditolak \\
\hline
\end{tabular}




$$
\begin{array}{ll}
\alpha 1=\operatorname{Min}\left(\mu_{\mathrm{IPKsdg}}(3,45), \mu_{\mathrm{SMTrdh}}(6), \mu_{\mathrm{POT} \text { dh }}(500)\right. & \alpha 2=\operatorname{Min}\left(\mu_{\mathrm{IPKsdg}}(3,45), \mu_{\mathrm{SMTrdh}}(6), \mu_{\mathrm{POTrdh}}(500)\right. \\
\left.\mu_{\mathrm{TLrdh}}(191.481), \mu_{\mathrm{PBBrdh}}(181.688), \mu_{\mathrm{TOTrdh}}(2)\right) & \left.\mu_{\mathrm{TLrdh}}(191.481), \mu_{\mathrm{PBBrdh}}(181.688), \mu_{\mathrm{TOT} s d g}(2)\right) \\
=\operatorname{Min}(0,1000 ; 1 ; 0,7750 ; 0,1426 ; 0,1916 ; 0,5000) & =\operatorname{Min}(0,1000 ; 1 ; 0,7750 ; 0,1426 ; 0,1916 ; 1) \\
=0,1000 & =0,1000
\end{array}
$$

\section{Defuzzyfikasi}

Mengambil tingkat keanggotaan maksimum dan minimum dari tiap konsekuen aplikasi fungsi, sehingga didapat daerah solusi Fuzzy sebagai berikut:

Mencari nilai $a_{1}, a_{2}=$

$=\frac{a-\text { minimal } \text { keputusan }}{\text { interval } \text { Keputusan }}=$ Nilai Keanggotaan

$=\frac{a_{1}-20}{50}=0,1000 \rightarrow a_{1}=25,00$

$=\frac{a_{2}-20}{50}=0,4500 \rightarrow a_{2}=42,50$

Fungsi Keanggotaan hasil komposisi $=$

$$
\mu[z]=\left\{\begin{array}{ccrl}
0,1000 ; & z & \leq 25,00 \\
(z-20) / 50 & 25,00 & \leq z \leq 42,50 \\
0,4500 ; & z & \geq 42,50
\end{array}\right.
$$

Menghitung $\mathrm{z}^{*}$ menggunakan metode centroid:

\section{Momen :}

$$
\begin{aligned}
& M 1=\int_{0}^{25,00}(0,1000 / 2) * z d z \\
& M 1=\int_{0}^{25,00} 0,\left.0500 z^{2}\right|_{0} ^{25,00} \\
& M 1=\int_{0}^{25,00} 0,0500 * 25,\left.00^{2}\right|^{25,00} 0 \\
& M 1=31,2500 \\
& M 2=\int_{25,00}^{42,50} \frac{(z / 20)}{50} * z d z \\
& M 2=\int_{25,00}^{42,50}\left(\frac{1}{50}-\frac{20}{50}\right) * z d z \\
& M 2=\int_{25,00}^{42,50}\left(0,02 z^{2}-0,4 z\right) d z \\
& M 2=171,3542
\end{aligned}
$$




$$
\begin{aligned}
& M 3=\int_{42,5}^{70}(0,45 / 2) * z d z \\
& M 3=\left.\int_{42,5}^{70}(0,225) * z^{2}\right|_{42,5} ^{70} \\
& M 3=696,0938
\end{aligned}
$$

\section{Luas :}

$$
\begin{aligned}
A 1 & =25,00 * 0,1000=2,5000 \\
A 2 & =\frac{(0,1000+0,4500) *(42,50-25,00)}{2} \\
& =\frac{9,6250}{2}=4,8125 \\
A 3 & =(70-42,50) * 0,450=12,3750
\end{aligned}
$$

\section{Sehingga :}

$$
\begin{aligned}
z^{*} & =\frac{M 1+M 2+M 3}{A 1+A 2+A 3} \\
& =\frac{31,2500+171,3542+696,0937}{2,5000+4,8125+12,375} \\
& =\frac{885,7395}{18,3347}=45,6481
\end{aligned}
$$

\subsection{Metode Optimasi Fuzzy Mamdani menggunakan Algoritma Genetika}

Calon penerima beasiswa dihitung menggunakan metode Algoritma Genetika, dengan menggunakan data yang dibangkitkan pada jumlah yaitu:
A. Jumlah Populasi $=100$ Populasi
B. Jumlah Generasi $=100$ Generasi
C. Crossover Rate $=0,2$
D. Mutasi Rate $=0,2$

Hasil uji coba dari Metode Optimasi Fuzzy Mamdani menggunakan Algoritma Genetika.

1. Data Calon Penerima Beasiswa

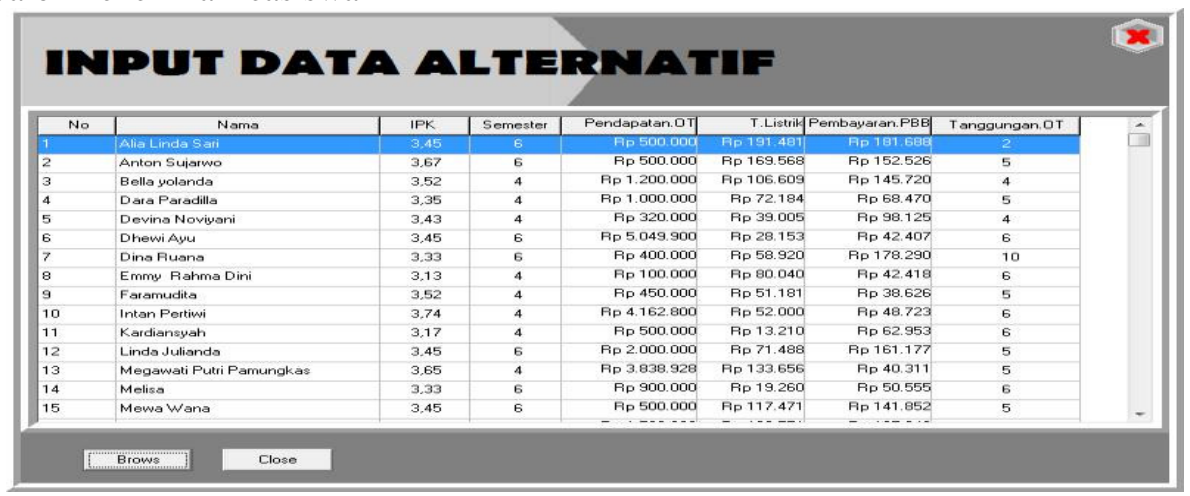

Gambar 14 Data Calon Penerima Beasiswa

2. Data Rule Fuzzy Mamdani

Pada penelitian ini digunakan Rule sebanyak 324 Rule dengan 6 kriteria. 


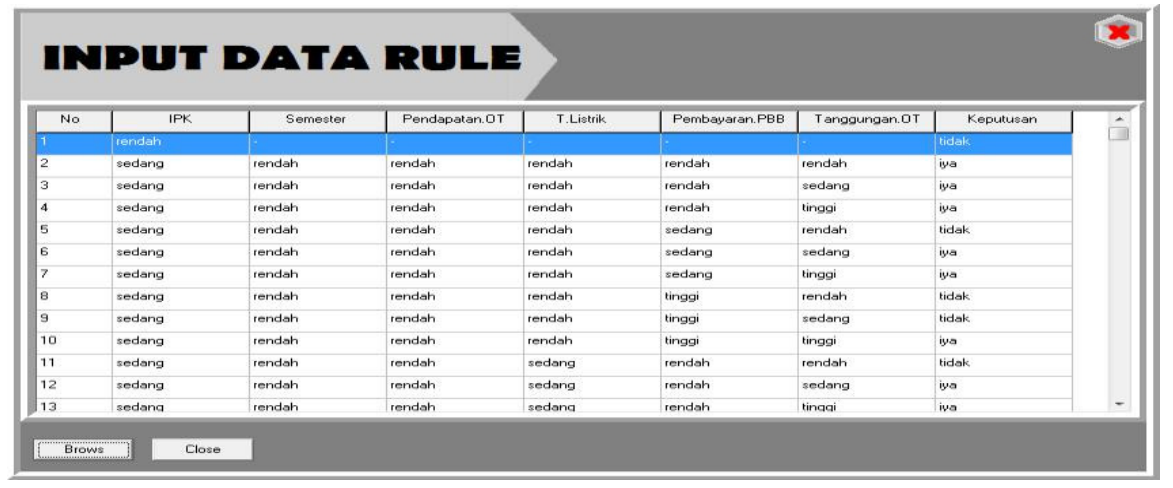

Gambar 15 Data Rule Fuzzy Mamdani

3. Proses Algoritma Genetika

Proses perhitungan algoritma genetika yang diterapkan pada borland delphi 7 .

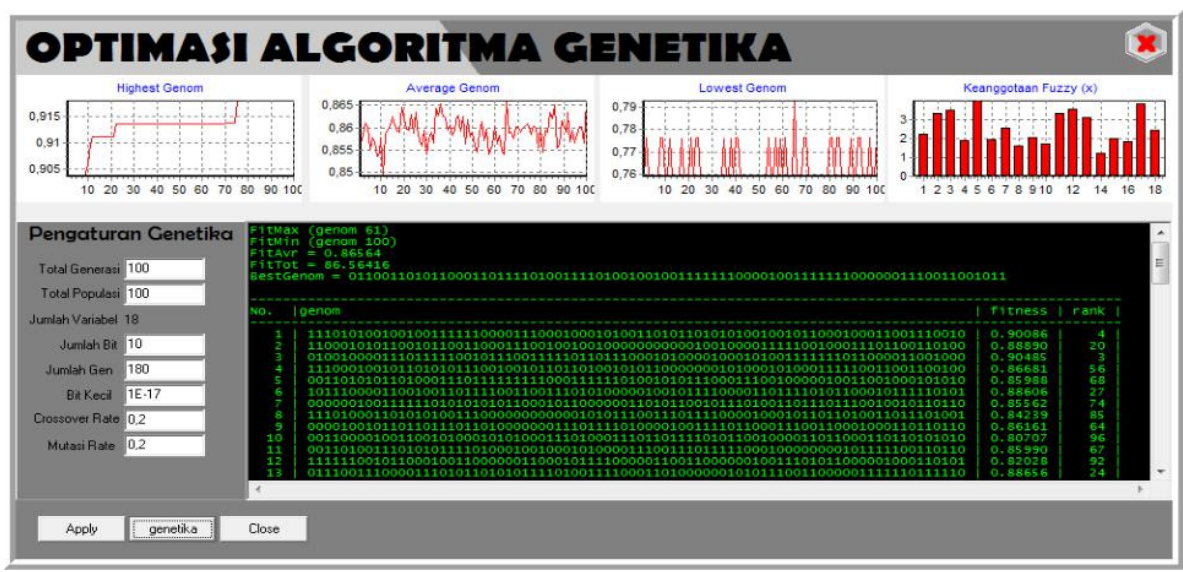

Gambar 16 Proses Algoritma Genetika

4. Grafik fungsi keanggotaan Fuzzy.

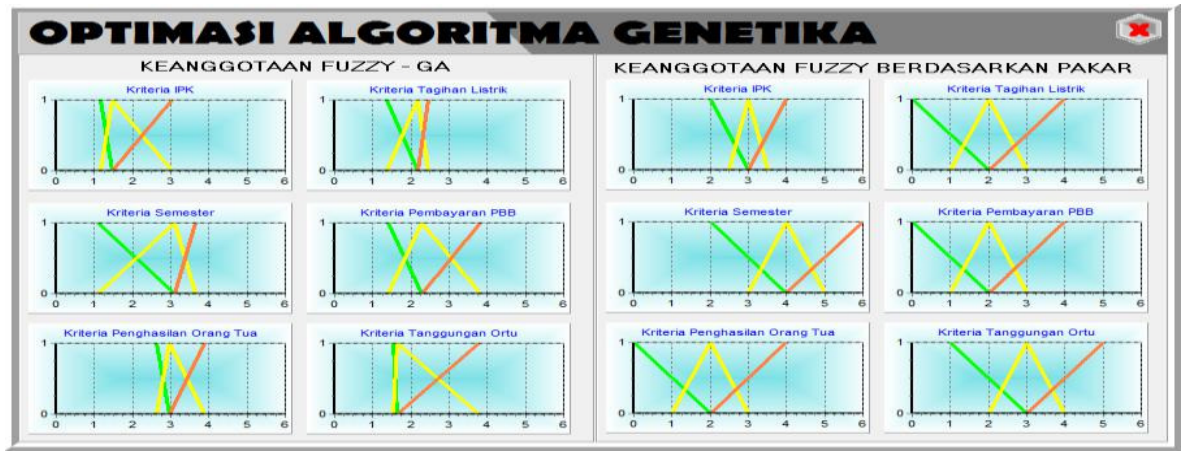

5. Gambar 17 Grafik fungsi keanggotaan Fuzzy

Hasil dari Optimasi Fuzzy Mamdani menggunakan Algoritma Genetika kecenderungan nilai fitness naik untuk setiap generasi. 


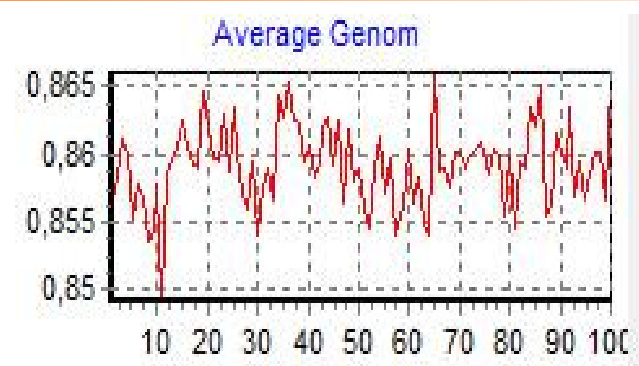

Gambar 18 Nilai Rata-rata fitness tertinggi pada 100 generasi

Gambar 18 merupakan representasi bentuk kromosom dengan nilai rata-rata fitness tertinggi pada 100 generasi yang dibangkitkan. Pada grafik fungsi keanggotaan diatas terlihat bahwa nilai grafik kecenderungan naik sampai pada sebuah nilai fitness tinggi tertentu.

\subsection{Hasil Evaluasi}

Hasil dari pengujian model yang dilakukan adalah memprediksi hasil dari pemilihan beasiswa di STMIK SuryaIntan Kotabumi yang dapat dilihat pada tabel sebagai berikut :

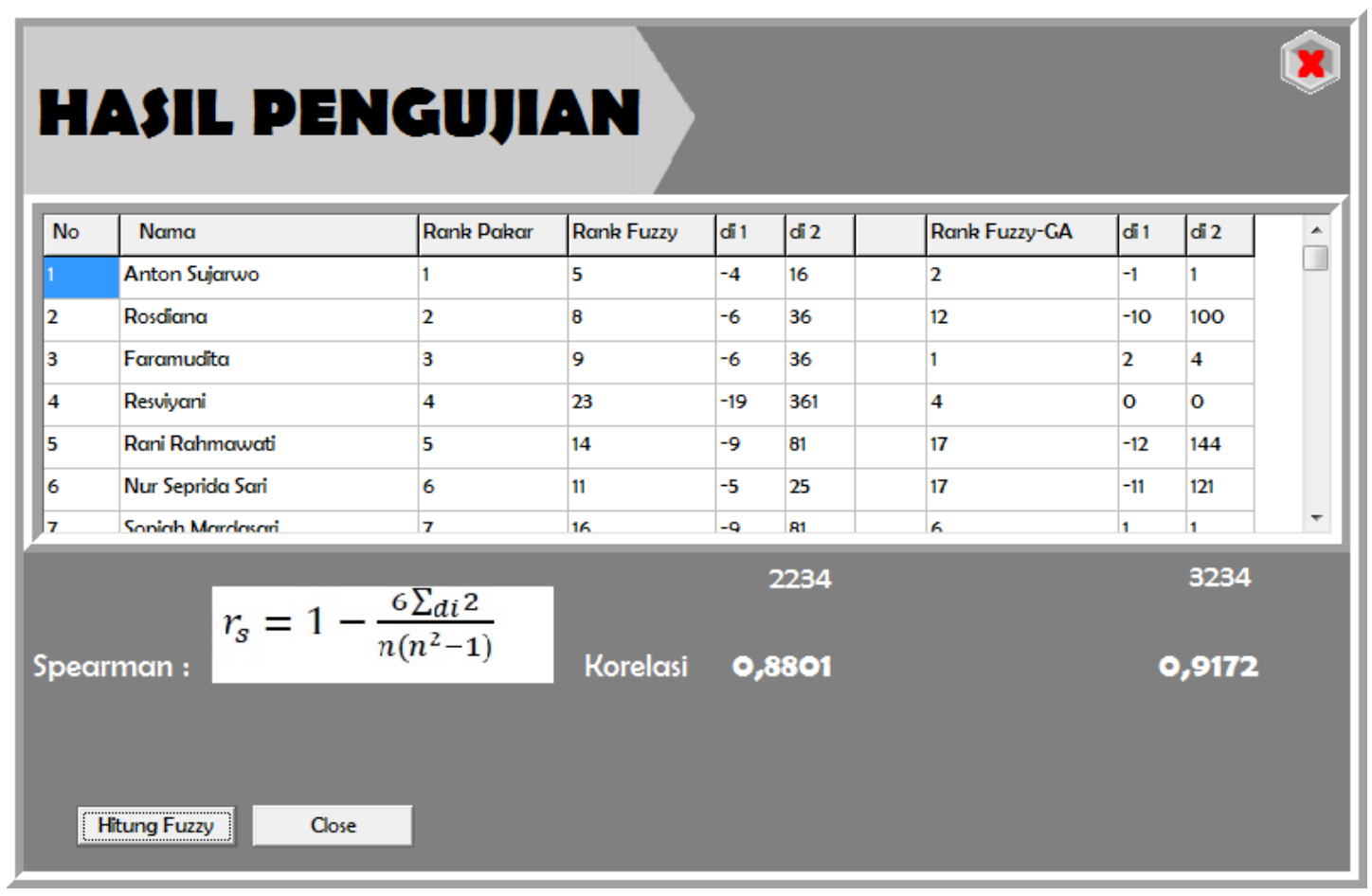

Gambar 19 Hasil Akurasi korelasi Rank Spearman

Akurasi dengan menggunakan Metode Fuzzy Mamdani menghasilkan nilai 0,8801 dan Optimasi Fuzzy Mamdani menggunakan Algoritma Genetika sebesar 0,9172 untuk menganalisis sebanyak 6 kriteria dan 30 record dalam menganalisis data mahasiswa. 


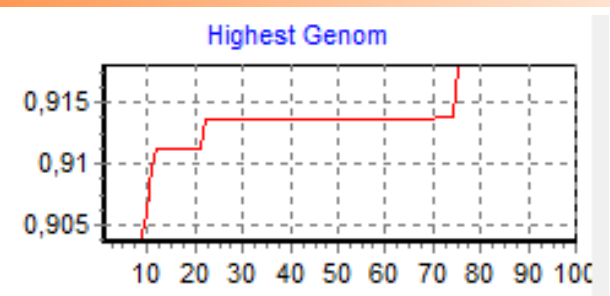

Gambar 20 Evaluasi korelasi Rank Spearman

Sesuai dengan grafik dan tabel diatas, tingkat akurasi dengan korelasi Rank Spearman menunjukkan peningkatan akurasi sebesar 0.0371 .

\section{Kesimpulan}

Dari hasil penelitian yang dilakukan, dapat diambil kesimpulan :

1) Optimasi fungsi keanggotaan Fuzzy Mamdani dengan algoritma genetika dapat digunakan dalam penentuan penerima beasiswa dengan hasil akurasi yang dapat ditingkatkan.

2) Pada proses pembentukan fungsi keanggotaan Fuzzy Mamdani menggunakan 6 variabel input yang dibangkitkan pada 100 generasi, 100 populasi dapat meningkatkan tingkat akurasi penentuan penerima beasiswa dengan fitness tertinggi adalah 0,9172 .

3) Hasil pengujian akurasi sistem optimasi keanggotaaan Fuzzy Mamdani menggunakan algoritma genetika dihasilkan nilai fitness tertinggi adalah 0,9172 dan hasil pengujian akurasi sistem Fuzzy Mamdani tanpa optimasi keanggotaan adalah sebesar 0,8801 dengan menggunakan perhitungan korelasi spearman. Namun waktu komputasi yang dibutuhkan lebih lama.

\section{Saran}

Dari hasil pengujian yang telah dilakukan saran atau usul yang di berikan antara lain:

1. Perlu adanya teknik yang dapat meminimalkan waktu komputasi pada mekanisme perbaikan kromosom pada algoritma genetika.

2. Metode crossover, mutasi, dan seleksi dapat digunakan dengan metode lainnya sehingga hasil akhir yang dihasilkan dapat lebih bervariasi dan menghasilkan hasil akhir yang lebih optimal.

\section{Daftar Pustaka}

[1] L. A. Latif, M. Jamil, and S. H. Abbas, Sistem Pendukung Keputusan Teori dan Implementasi. Yogyakarta: Deepublish, 2018.

[2] Wikipedia, "Beasiswa," id.wikipedia.org, 2019. [Online]. Available: https://id.wikipedia.org/wiki/Beas iswa.

[3] B. Hosseinzadeh, H. Zareiforoush, M. E. Adabi, and A. Motevali, "Development of a Fuzzy Model to Determine the Optimum Shear Strength of Wheat Stem," Int. J. Comput. Sci. Telecommun., vol. 2, no. 4, pp. 56-60, 2011.

[4] N. Siddique, "Intelligent control: a hybrid approach based on fuzzy logic, neural networks and genetic algorithms," Springer, vol. 517, 2014.

[5] S. Kusumadewi and H. Purnomo, Aplikasi Logika Fuzzy untuk Pendukung Keputusan. Yogyakarta: Graha Ilmu, 2010. 
[6] T. J. Ross, FUZZY LOGIC WITH ENGINEERING ENGINEERING Third Edition. New Mexico: John Wiley \& Sons, Ltd, 2010.

[7] B. D. Setiawan and Subanar, "Color pixel classification using genetic fuzzy system: Case study on earth surface classification," 2010 Int. Conf. Distrib. Fram. Multimed. Appl., pp. $1-6,2010$.

[8] B. A. Restuputri, W. F. Mahmudy, and I. Cholissodin, "Optimasi Fungsi Keanggotaan Fuzzy Tsukamoto Dua Tahap Menggunakan Algoritma Genetika Pada Pemilihan Calon Penerima Beasiswa dan BBP-PPA ( Studi Kasus : PTIIK Universitas Brawijaya Malang )," Repos. J. Mhs. PTIIK Univ. Brawijaya, vol. 5, no. 15, pp. 1-10, 2015.

[9] T. Sutojo, E. Mulyanto, and V. Suhartono, Kecerdasan Buatan. Andi Offet, 2011.

[10] Sugiyono, Metode penelitian pendidikan:(pendekatan kuantitatif, kualitatif dan $R \& D$ ). Alfabeta, 2008. 